\title{
Development of Teaching Material with the Creative Problem Solving Model Using Mobile Learning Application
}

\author{
Aisyah Sukmafani a , Munzil ${ }^{\text {b, }}$, Isnanik Juni Fitriyah ${ }^{\text {c }}$ \\ a,b,c Uiversitas Negeri Malang, Semarang Street, Number 5, \\ Malang, East Java, Indonesia \\ *Corresponding author's e-mail: munzil.fmipa@um.ac.id
}

\begin{abstract}
This study and development aimed to produce a valid and feasible teaching material with the Creative Problem Solving (CPS) model on the activity of environmental pollution analysis using a mobile learning application in the COVID-19 pandemic era. The study model in this development was using the ADDIE method that limited to analyze, design, and develop stages where each stage passes the evaluation stage. The validity rate of the teaching material is obtained through a validity test by the validator while its eligibility rate is obtained through feasibility tests by the users. The validation result of materials in the teaching material had a percentage of $93.31 \%$ and the media feasibility test obtained a percentage of $95.60 \%$. This teaching material was packed in a mobile learning form that consists of water, air, and land pollution materials. This teaching material displayed news articles, materials explanations, and presented in the form of animated videos, phenomena videos, pictures of environmental pollution, student worksheets, and mission-based learning activities. Animated videos have three animation characters that move and talk with different voices in each sub-chapter. The validation result by validators stated that the teaching material is valid and feasible, with a percentage of $\geq 81 \%$.
\end{abstract}

\section{Introduction}

Science and technology development in the 21st-century affects all human life aspects, including the education aspect. Education has responsibilities and challenges to generate human resources that can solve various problems [1]. One of the means to come up with qualified human resources is through science learning. Science learning teaches each student to solve every problem using skills, attitude, and science concepts development based on daily experiences. Science learning emphasizes direct experiences to help students develop and understand their 
environment scientifically. It facilitates students to obtain and build a more concrete and meaningful understanding of the surrounding nature [2].

Meaningful learning can help students to implement their knowledge in daily life. Meaningful learning directly involves and educates students to face problems and seek solutions based on given information. Meaningful learning is useful to improve students' activeness and creativity to create new ideas [3]. Creativity on individuals can be in the form of new ideas creation as the result of problem-solving, determining the suitable solution, and applying the solution. Students' creativity can be enhanced through an innovative, creative, and fun learning, as well as a learning process that motivates students to be more active in class [4]. All materials in science demand students to be active during the learning process, especially the ecosystem's environmental pollution material. Problems regarding environmental pollution are closely related to students' life.

Learning processes in the field are mostly presented monotonously and not appealing. It causes the absence of information exchange and material meaning in the learning process on students [5]. A monotone and boring lesson cannot enhance creativity and demotivates students. Students' creative thought cannot be developed without individual learning interest [6].

A motivating and creativity-enhancing lesson can be actualized using teaching materials that facilitate students and teachers to exchange information. Based on observation results conducted at Middle School 8 of Malang, teaching materials used are books, videos, and PowerPoint slides. Material capacity in books perceived to be not sufficient because the problems and solutions are book-based. Problems regarding environmental pollution are intricate, and the utilization of books and lectures are inadequate. Another activity to be conducted is environment observation, but it has a time-consuming weakness for students' learning time [7].

Learning processes that only use textbooks do not pay attention to creative development in studebts. Textbooks are inadequate to motivate, contain talents, interests, and potentials of students. Students only focus on answers and materials in the book so that their creative thoughts are obstructed [8]. Indonesia's rank supports Sohibi and Siswanto's statement in The Global Creativity Index. Indonesia fell to the 81 st rank of 82 countries in 2010 [9] and the 115 th of 139 countries in 2015 [10].

Teaching materials development is conducted to motivate, attract, and enhance students' creativity by giving roles in building knowledge according to their skills and experiences [11]. Teaching materials mentioned can be as mobile learning on a smartphone. Based on the interview result of students at Middle School 8 of Malang, students prefer smartphone learning than other 
learning materials. Students can utilize smartphones to obtain the required information. This result is supported by The 2018 Cambridge International Global Census that stated that Indonesia was the runner up of countries with the most smartphone users, with a percentage of $67 \%$, and $81 \%$ of Indonesian children used smartphones to do their homework [12]. Mobile learning can be used as a teaching material alternative operated by smartphones or PC tablets [13]. Teaching material of mobile learning can be independently operated and enhance students' interest in the learning process $(14,15)$.

A learning process that develops students' creativity is insufficient if mobile learning application is the only applied teaching material, and teaching material with learning activities that trigger students' creativity is required. Problem-based learning aims to help students arrange and facilitate them during the learning process on a different level [16]. The provided teaching material to solve creative thinking problems can create an effective and fun learning process [17].

The current (2019-2020) ongoing problem is the emergence of a pandemic from the corona virus (SARs-COV-2). This pandemic affects the economy, tourism, social, and education. UNESCO (2020) stated that COVID-19 pandemic's impacts in the educational sector caused the closing of 144 educational institutions by the government to stop the virus from spreading, and 1.18 billion students are affected pandemic. UNESCO's solution to face this pandemic is to conduct distance learning by enhancing teachers' and sources' role in utilizing the developed technology such as smartphones [18]. According to the circular letter of the Ministry of Education and Culture of the Republic of Indonesia (Kemdikbud) regarding the implementation of education policies in times of COVID-19 deployment emergencies, the learning activity should be conducted from home using online learning [19].

A learning activity that enhances students' creativity can be found in the Creative Problem Solving (CPS) model. The CPS model is a learning model with a constructive approach, so that students act as a learning center. The CPS model can be applied to students who have various abilities. The CPS model is not limited to the level of introduction, understanding and application of the material, but to train students to be able to analyze a problem and solve problems [20]. Student creativity is a process of organizing learning, reasoning and logic in order to produce an understanding of the situation at hand. The CPS model helps students to develop ideas in order to know the conditions of an environment and change these ideas to solve a problem [21].

Development of teaching material with the CPS model can help students identify problems, generate ideas and develop solutions. Teaching materials developed using the CPS model contain 
various problems so that students are able to increase creativity in solving complex problems. The CPS model teaching materials provide facilities for students to be directly involved in all activities so that students are able to develop their thinking skills [22]. CPS model teaching materials help students to be more creative in the problem solving process [23]. The CPS model is useful to train students' creativity skills to solve problems. The CPS model offers students chances to build and generate creative ideas when they face a problem [24]. Based on the discussed review, authors developed a teaching material with the creative problem solving (CPS) model on the activity of environmental pollution analysis using mobile learning application.

\section{Method}

This study method used the ADDIE study and development model that is limited to four stages, i.e., Analyze, Design, Develop, and each stage to pass the Evaluate stage [25]. The Analyze stage has five steps to discover the possibilities of students' problems. The design stage comprises three steps to verify targeted performance and suitable testing methods. The Develop stage consists of four steps to produce and validate developed teaching material products. At the end of each ADDIE model stage, it had to pass the Evaluate stage to assess the developed teaching material product quality throughout manufacturing to product formation.

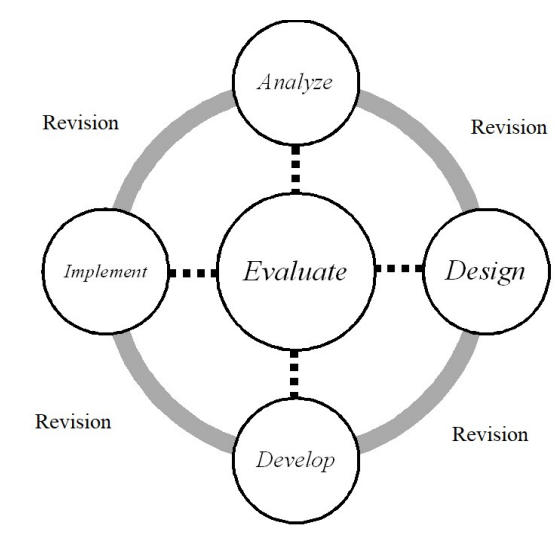

Figure 1. Diagram of the ADDIE Development Model

(Source: Branch, 2009)

The developed product's feasibility and validity were assessed by validators using an assessment instrument of validation questionnaire. Test subjects in this teaching material development were two science teachers who have taught science for a minimum of 7 years. Data obtained were qualitative and quantitative data. The quantitative data were obtained from the Likert Scale and Guttman Scale scoring. Meanwhile, the qualitative data was obtained from the suggestions and comments of validators. The data analysis technique used was descriptive analysis 
by calculating the average percentage of validated scores. Criteria on the Likert scale are shown in Table 1.

Table 1.

\section{Likert Scale}

\begin{tabular}{|c|c|}
\hline Score & Information \\
\hline 4 & $\begin{array}{l}\text { If respondent gives an assessment of very good/very interesting/very clear/very } \\
\text { feasible. }\end{array}$ \\
\hline 3 & If respondent gives an assessment of good/ interesting/ clear/ feasible. \\
\hline 2 & If respondent gives an assessment of less good/less interesting/less clear/less feasible. \\
\hline 1 & If respondent gives an assessment of not good/not interesting/unclear/not feasible. \\
\hline
\end{tabular}

Source: Likert (1932)

This study also used the Guttman scale to verify the material concept truth in the teaching material product. Scoring criteria on this scale are shown in Table 2.

Table 2.

Guttman Scale

\begin{tabular}{cc}
\hline Score & Criteria \\
\hline 1 & Yes \\
0 & No \\
\hline
\end{tabular}

Source: Guttman (1944)

The quantitative data analysis was conducted by calculating the average score answer of each aspect. According to Riduwan (2009), the calculation formula to discover a product's feasibility is as follows.

$$
P=\frac{\sum x}{n} \times 100 \%
$$

$\mathrm{P} \quad=$ Validity Percentage

$\Sigma \mathrm{x} \quad=$ The number of answer score of validators

$=$ The number of maximum score in assessment aspects

Based on validity data results, product feasibility criteria is determined. The validity criteria of the calculation result are adjusted to Table 3. 
Table 3.

Validity Percentage Scale

\begin{tabular}{cc}
\hline Percentage (\%) & Criteria \\
\hline $0-20$ & Not good/not feasible \\
$21-40$ & Less good/less feasible \\
$41-60$ & Quite good/quite feasible \\
$61-80$ & Good/Feasible \\
$81-100$ & Very good/very feasible \\
\hline
\end{tabular}

Source: Riduwan (2009)

A product is declared valid if the percentage score is $\geq 61 \%$, and therefore is feasible to be used as teaching material in a learning process. If the score is $\leq 60 \%$, then the developed product has to be repaired.

\section{Results}

The product that had passed the development stage then entered the validation stage to discover the teaching material's validity and feasibility level. Validation was conducted by validators of science education lecturers and science teachers who have taught for a minimum of 7 years. There were three validation questionnaires, including the material truth validation questionnaire, a teaching material validation questionnaire, and the teaching material media feasibility validation questionnaire. Data obtained from the validation result are quantitative and qualitative. The quantitative data were achieved from calculating the average value from validators on each aspect, while the qualitative data were achieved from comments and suggestions from validators. The material truth quantitative data obtained an average percentage of 1 with true criteria. Then, teaching material validation was conducted. The teaching material validation quantitative data result is presented in Table 4.

Table 4.

Results of Material Test Validation Quantitative Data in Teaching Material

\begin{tabular}{clcc}
\hline No & \multicolumn{1}{c}{ Assessment Aspect } & Percentage & Information \\
\hline 1 & Basic Competencies and Learning Objectives & $100.00 \%$ & Very Feasible \\
2 & Concept Map & $100.00 \%$ & Very Feasible \\
3 & Language Feasibility & $88.89 \%$ & Very Feasible \\
4 & Explore the Vision & $94.44 \%$ & Very Feasible \\
5 & Gather Data & $97.22 \%$ & Very Feasible \\
6 & Formulate Challenges & $91.67 \%$ & Very Feasible \\
7 & Explore Ideas & $87.50 \%$ & Very Feasible \\
8 & Formulate Solution & $90.28 \%$ & Very Feasible \\
9 & Formulate a Plan & $89.81 \%$ & Very Feasible \\
& Total Average & $\mathbf{9 3 . 3 1 \%}$ & Very Feasible \\
\hline
\end{tabular}


The average percentage of material validation data obtained $93.31 \%$ with very feasible criteria. Material truth validation qualitative data is shown in Figure 2.

\begin{tabular}{|l|l|}
\hline \multicolumn{1}{|c|}{ Validator } & Comment and Suggestion \\
\hline Validator 1 & a. Repetitive words are better written completely \\
\hline
\end{tabular}

Figure 2. Results of Material Test Validation Qualitative Data in Teaching Material

After the material validation, the media feasibility validation was conducted. The media feasibility validation quantitative data result is presented in Table 5.

\section{Table 5.}

Results of Teaching Material Feasibility Validation Quantitative Data

\begin{tabular}{clcc}
\hline No & \multicolumn{1}{c}{ Assessment Aspect } & Average & Information \\
\hline 1 & Cover screen & $100 \%$ & Very Feasible \\
2 & Prologue & $100 \%$ & Very Feasible \\
3 & Content design & $89.60 \%$ & Very Feasible \\
4 & Button & $100 \%$ & Very Feasible \\
5 & News articles & $91.70 \%$ & Very Feasible \\
6 & Material explanation & $87.50 \%$ & Very Feasible \\
7 & Link & $100 \%$ & Very Feasible \\
8 & Pictures & $91.70 \%$ & Very Feasible \\
9 & Videos & $100 \%$ & Very Feasible \\
& Total Average & $\mathbf{9 5 . 6 0 \%}$ & Very Feasible \\
\hline
\end{tabular}

The average percentage of media validation data obtained $95.60 \%$ with very feasible criteria. Media feasibility validation qualitative data is shown in Figure 3.

\begin{tabular}{|c|ll|}
\hline Validator & \multicolumn{1}{|c|}{ Comment and Suggestion } \\
\hline Validator 2 & $\begin{array}{l}\text { a. } \\
\text { b. }\end{array}$ & $\begin{array}{l}\text { Tverall, the teaching material is good. } \\
\text { online learning process }\end{array}$ \\
\hline
\end{tabular}

Figure 3. Resultf of Teaching Material Feasibility Validation Qualitative Data

\section{Discussion}

\section{a. Description of Study and Development Results}

The end developed product is a teaching material with the Creative Problem Solving (CPS) model on the activity of environmental pollution analysis using a mobile learning application. The product was developed using the application as the learning media operated by smartphones to enhance learning activity efficiency [13]. This teaching material was accessed online by paying attention to the determined smartphone specification. The effort of utilizing IT-based learning in 
the form of learning applications on smartphones (mobile learning) can boost students' activeness to learn wherever and whenever [29].

This product comprises two components, namely supporting and main components. Supporting components consist of audios (back sound, buttons, and dubbing for each character), cover screen, home, manual for use, prologue, developer's profile, and references. The main components consist of learning objectives, concept maps, news articles, explanations of materials, and missions on each sub-chapter. This teaching material product was used to support teaching material consisting of material explanations, students' worksheets, and experiment activities. Students' worksheets were in each mission as google form. The application is equipped with news articles, animation videos, and phenomenon videos regarding environmental pollution. This product has three subchapters packed in animation videos. The mentioned animation videos are three characters moving and talking using different sounds on each sub-chapter. Animation videos are illustrated as poor shape due to the impacts of environmental pollution. Students could analyze environment phenomena and provide a solution based on their learning activities [14], [26].

This teaching material is interactive because there was a direct interaction between students and each character in the material during the learning activity. Animation videos presented in poor shape will back to being clean by students' role in accomplishing every mission. Throughout learning activities presented on each mission, students also played a role in helping characters back to being clean. It happened when students were on the second (Explore Ideas) and fourth (Formulate a Plan) missions before the Quiz, where these two missions presented changes in each character due to students' roles. This teaching material helps students conduct skills on BC 4.8, i.e., creating a written idea on problem-solving of environmental pollution based on observation, video analysis, and discussion. The experiment activity was conducted by observing and analyzing environmental pollution phenomena videos presented on each island in Indonesia. It aimed to facilitate students to observe the surrounding environment.

Missions on the product are of main components. Each mission was adjusted to learning activities on the CPS model, including Explore the Vision, Gather Data, Formulate Challenges, Explore Ideas, Formulate Solution, and Formulate a Plan [27]. Cover screen and component snippet is shown in Figure 4. 


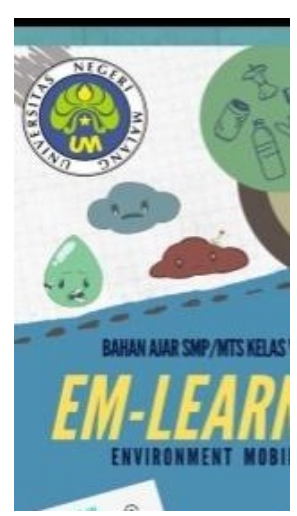

(a)

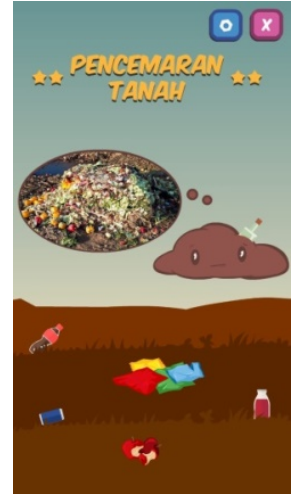

(b)
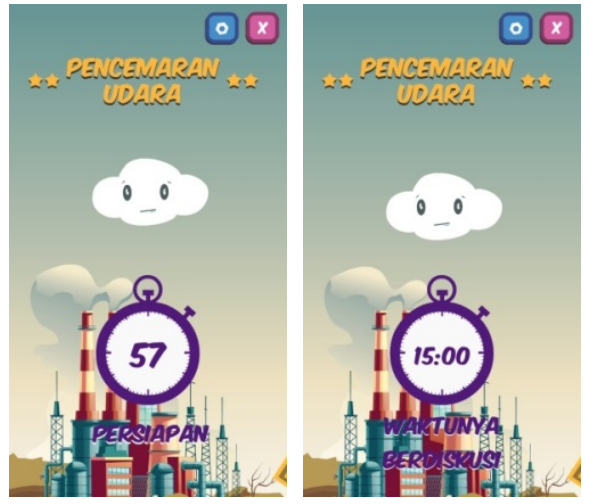

(c)

Figure 4. (a) Application cover screen presentation, (b) Screen presentation of the Gather Data stage in the sub-chapter of Land Pollution, (c) Screen presentation of the Formulate a Plan in the sub-chapter of Air Pollution

\section{b. Product Validation}

Based on the data analysis results of validation questionnaires by three validators, the developed product is stated to achieve a score of $94.45 \%$ with very feasible criteria. The media feasibility quantitative data obtained a percentage of $95.60 \%$ with very feasible criteria. Product presentation, story plot in prologue, easiness to access the application using buttons, easiness to access links and videos in the product, had the highest percentage during the product feasibility test, while supporting media in the material explanation had the lowest percentage of $87.50 \%$. The material validation result had a percentage of $93.31 \%$ from several assessed aspects. Learning objectives and concept maps in the teaching material had the highest percentage during the validation process of $100 \%$, while the Explore Ideas activity on the CPS model syntax had the lowest percentage of $87.50 \%$. The concept or material truth quantitative data analysis result obtained a score of 1 , meaning that all materials in the teaching material are true. Based on the validation result, it can be concluded that the teaching material with the Creative Problem Solving (CPS) model in analyzing environmental pollution with mobile learning application is valid and feasible. Therefore, this teaching material can be used in analyzing environmental pollution activity.

\section{Conclusion}

Study and development conducted resulted in a teaching material with the Creative Problem Solving (CPS) model on the activity of environmental pollution analysis. The teaching material is of a mobile learning application. The data analysis result shows that the developed teaching material can be categorized as feasible and valid with a percentage of $\geq 81 \%$. The results of the 
media feasibility questionnaire analysis in teaching materials obtained a percentage of $95.60 \%$ with very feasible criteria, so it can be seen that the media used in the teaching materials are in accordance with the material presented. The result of material validation has a percentage of 93.31\% with very feasible criteria, so it can be seen that the teaching materials developed have met the standards in every aspect of the assessment.

\section{References}

[1] Yuliati Y. Literasi Sains Dalam Pembelajaran IPA. J Cakrawala Pendas. 2017;3(2):21-8.

[2] Ali LU, Suastra W, Sudiatmika AAIAR. Pengelolaan Pembelajaran IPA Ditinjau Dari Hakikat Sains Pada SMP Di Kabupaten Lombok Timur. Prism Sains J Pengkaj Ilmu dan Pembelajaran Mat dan IPA IKIP Mataram. 2013;3:103.

[3] Zubaidah S, Fuad NM, Mahanal S, Suarsini E. Improving creative thinking skills of students through Differentiated Science Inquiry integrated with mind map. J Turkish Sci Educ. 2017;14(4):77-91.

[4] Hall C, Kent SC, McCulley L, Davis A, Wanzek J. A New Look at Mnemonics and Graphic Organizers in the Secondary Social Studies Classroom. Teach Except Child. 2013;47-55.

[5] Praptanti I, Eka KI. Penerapan Konsep Pembelajaran Aktif, Kreatif, Efektif, dan Menyenangkan (PAKEM) Dalam Menyimak Puisi untuk Meningkatkan Kemampuan Apresiasi Sastra. Artik Penelit [Internet]. 2011; Available from: https://media.neliti.com/media/publications/217698-penerapan-konsep-pembelajaran-aktifkrea.pdf

[6] Abdurrozak R, Jayadinata AK. PENGARUH MODEL PROBLEM BASED LEARNING TERHADAP KEMAMPUAN BERPIKIR KREATIF SISWA. J Pena Ilm. 2016;1(1).

[7] Atikasari S, Isnaeni W, Prasetyo APB. PENGARUH PENDEKATAN PROBLEM-BASED LEARNING DALAM MATERI PENCEMARAN LINGKUNGAN TERHADAP KEMAMPUAN ANALISIS. J Biol Educ [Internet]. 2012;1(3):211-8. Available from: http://journal.unnes.ac.id/sju/index.php/ujeb\%0AKESIAPAN

[8] Sohibi M, Siswanto J. Pengaruh Pembelajaran Berbasis Masalah Dan Inkuiri Terbimbing Terhadap Kemampuan Berpikir Kritis Dan Kreatif Siswa. J Penelit Pembelajaran Fis. 2012;3(2/SEPTEMBE):135-44.

[9] Florida R, Mellander C, Stolarick K. Creativity and prosperity: the global creativity index. 2011;54. Available from: https://tspace.library.utoronto.ca/handle/1807/80125 
[10] Florida R, Mellander C, King K. The Global Creativity Index 2015. Martin Prosper Inst [Internet]. 2015;68. Available from: http://martinprosperity.org/media/Global-Creativity-Index2015.pdf

[11] Grevitara Y, Suarsini E, Prabaningtya S. PENGEMBANGAN BAHAN AJAR MULTIMEDIA INTERAKTIF MATERI PERUBAHAN LINGKUNGAN / IKLIM UNTUK SISWA KELAS X SMAN 1 MOJOSARI MELALUI HASIL PENELITIAN BIODEGRADASI LIMBAH CAIR INDUSTRI PENYAMAKAN KULIT. 2013;1-13.

[12] Cambridge Assessment International Education. Global Education Census Report. 2018;16. Available from: https:/www.cambridgeinternational.org/Images/514611-global-educationcensus-survey-report.pdf

[13] Subekti H, Taufiq M, Susilo H, Ibrohim, Suwono H. Mengembangkan Literasi Informasi Melalui Belajar Berbasis Kehidupan Terintegrasi Stem Untuk Menyiapkan Calon Guru Sains Dalam Menghadapi Era Revolusi Industri 4.0: Revieu Literatur. Educ Hum Dev J. 2017;3(1):81-90.

[14] Singh AAG, Leavline EJ, Selvam J. Mobile Application for m-Learning. Int J Adv Res Comput Sci. 2017;8(4):313-7.

[15] Drigas AS, Pappas MA. A R EVIEW OF M OBILE L EARNING A PPLICATIONS FOR M ATHEMATICS . A Review of Mobile Learning Applications for Mathematics . Int J Interact Mob Technol. 2015;9(3):18-23.

[16] Ninck A. Creative problem solving as a learning process. Syst Cybern INFORMATICS [Internet]. 2013;11(9):100-5. Available from: http://www.iiisci.org/Journal/CV\$/sci/pdfs/iGA663UP.pdf

[17] Swestyani S, Masyuri M, Prayitno BA. Pengembangan Modul IPA Berbasis Creative Problem Solving ( CPS ) untuk Meningkatkan Kemampuan Berpikir Kreatif Siswa Development of Creative Problem Solving ( CPS ) -based Integrated Natural Science Module to Improve Student s ' Creative Thinking. J Pembelajaran Biol. 2014;6(2):36-41.

[18] UNESCO. UNESCO COVID-19 Education Response. Education Sector issue notes: Distance learning strategies in response to COVID-19 school closures. 2020;(April):1-8.

[19] Kementerian Pendidikan dan Kebudayaan Republik Indonesia. Surat Edaran Nomor 4 Tahun 2020 Tentang Pelaksanaan Kebijakan Pendidikan Dalam Masa Darurat Penyebaran Coronavirus Disease (COVID-19). 2020;1-3.

[20] Nur I, Udiyah M, Pujiastutik H. Implementation of Creative Problem Solving ( CPS ) to the Problem Solving Ability IPA Class VII SMP Negeri 2 Tuban. Proceeding Biol Educ Conf. 2017;14(1):540-4. 
[21] Tutorialspoint. Creative Problem Solving. 2019;1-13.

[22] Jailani, Sugiman, Retnawati H, Bukhori, Apino E, Djidu H, et al. Desain Pembelajaran Matematika Untuk Melatih Higher Order Thinking Skills. Pertama. Retnawati H, editor. UNY Press. Yogyakarta: UNYPRESS; 2018.

[23] Apostolov G, Milenkova V. MOBILE LEARNING AND DIGITAL LITERACY IN THE CONTEXT OF UNIVERSITY YOUNG ADULTS. 2018;105-12.

[24] Sumarli, Nugroho SE, Yulianti I. Keefektifan Model Pembelajaran Creative Problem Solving Berpendekatan Inquiry terhadap Keterampilan Proses Sains Siswa. 2018;2(1):63-9.

[25] Branch RM. Instructional Design: The ADDIE Approach. Vol. 91, Foreign Affairs. USA: Springer; 2009. 1-203 p.

[26] Likert R. A TECHNIQUE FOR THE MEASUREMENT OF ATTITUDES. 1932;22:5-55.

[27] Guttman L. A Basis for Scaling Qualitative Data. Am Sociol Rev. 1944;9(2):139.

[28] Riduwan S. Pengantar Statistika untuk Penelitian Pendidikan, Sosial, Ekonomi, Komunikasi dan Bisnis. Penerbit Alfabeta. Bandung. 2009.

[29] Astra IM, Nasbey H, Nugraha A. Development of an android application in the form of a simulation lab as learning media for senior high school students. Eurasia J Math Sci Technol Educ. 2015;11(5):1081-8.

[30] Creative Education Foundation. Creative Problem Solving Resource Guide. 2015; from: http://www.creativeeducationfoundation.org/wp-content/uploads/2015/06/ToolsTechniquesGuide-FINAL-web-watermark.pdf 